\title{
Models Applied to Grapevine Pests: A Review
}

\author{
Federico Lessio and Alberto Alma *
}

check for updates

Citation: Lessio, F.; Alma, A. Models Applied to Grapevine Pests: A Review. Insects 2021, 12, 169. https://doi.org/10.3390/insects 12020169

Academic Editor: Alberto Pozzebon Received: 30 December 2020

Accepted: 11 February 2021

Published: 16 February 2021

Publisher's Note: MDPI stays neutral with regard to jurisdictional claims in published maps and institutional affiliations.
DISAFA, Entomology Unit, University of Torino, Largo Braccini 2, 10095 Grugliasco (TO), Italy; federico.lessio@unito.it

* Correspondence: alberto.alma@unito.it; Tel.: +39-11-6708534

Simple Summary: Mathematical models are developed to predict key aspects of insects harmful to many crops, including grapevine. Practical applications of these models include forecasting seasonal occurrence and spread over space in order to make decisions about pest management (e.g., timing of insecticide sprays). Many models have recently been developed to evaluate the spread of insect pests on grapevine under a climate change scenario as well as to forecast the possibility that alien species could settle into new environments. To make the published models available to vine-growers and their stakeholders, a holistic approach presenting these models within the frame of a decision support system should be followed.

Abstract: This paper reviews the existing predictive models concerning insects and mites harmful to grapevine. A brief conceptual description is given on the definition of a model and about different types of models: deterministic vs. stochastics, continuous vs. discrete, analytical vs. computer-based, and descriptive vs. data-driven. The main biological aspects of grapevine pests covered by different types of models are phenology, population growth and dynamics, species distribution, and invasion risk. A particular emphasis is put on forecasting epidemics of plant disease agents transmitted by insects with sucking-piercing mouthparts. The most investigated species or groups are the glassywinged sharpshooter Homalodisca vitripennis (Germar) and other vectors of Xylella fastidiosa subsp. fastidiosa, a bacterium agent of Pierce's disease; the European grape berry moth, Lobesia botrana (Denis and Schiffermuller); and the leafhopper Scaphoideus titanus Ball, the main vector of phytoplasmas agents of Flavescence dorée. Finally, the present and future of decision-support systems (DSS) in viticulture is discussed.

Keywords: grapevine; pest management; modelling; decision-support system; Xylella fastidiosa; Lobesia botrana; Scaphoideus titanus

\section{Introduction}

Arthropod pests cause yearly heavy losses in viticulture. The cost of pest management is constantly increasing due to a lack of active ingredients, the introduction of alien species, and so on. Optimization of pest management strategies is therefore a key point in viticulture. Pest management in viticulture should follow an integrated approach, including chemical sprays, biological control agents, agroecology, mating disruption, and forecast models [1]. The latter represent a useful set of tools, as they allow us to make timely decisions in targeting pests or considering a particular factor of risk. The main (ultimate) purpose of a model in agriculture is to produce a pest-management decisionsupport system (DSS) [2,3]. This fits phenological and demographical models, which allow for a forecast of insect population dynamics over time, permitting to drive insecticidal sprays [4]. Another frequently covered issue is risk assessment, for which the output of the model is often a risk map [5,6]. The geographical displacement of insect pests is also a stressed point within the frame of a climate-changing scenario. Nevertheless, bringing the potential benefit of using modelling tools to the stakeholders (e.g., extension services and farmers) often represents a challenge to scientists [3]. Although many models in grapevine 
entomology are about single species, the future of modelling in pest management should be directed towards comprehensive frameworks, embracing more aspects of the problem, e.g., economics, crop yields, etc., in which the insect pest becomes a part of the whole [6]. For instance, it may become necessary to make a choice about timing of insecticidal sprays against two different pests overlapping within the season, and if both pests are forecasted by a model, it would be easier to choose the best active ingredient, making the decision eco-friendlier and cheaper.

In this review, we go over the state-of-art of the different models designed and applied to insect pests of grapevines worldwide, investigating their utilities and limits and defining their actual and potential applications in decision-support systems (DSS). While the main part of the species overviewed are modelled with exact reference to grapevine, some of them have been modelled referring to other host plants but are listed here since such pests can be harmful to grapevine too. We start with a brief review of the basic concepts of modelling and then list the different types of models that have been implemented with regard to grapevine insect pests. Finally, we focus on the building and application of different types of models for some of the most important grapevine pests or diseases transmitted by pests. The literature was reviewed using the search engines Scopus, Web of Science, and Google Scholar, and the search period ranged from 1990 to 2020. The following keywords (listed here alphabetically) were used in multiple combinations: berry moth(s), calibration, climate change, decision-support system, demographic, deterministic, entomology, epidemiology, Eupoecilia ambiguella, insects, invasion risk, leafhoppers, Lobesia botrana, mealybugs, model (modelling), grape, grapevine, parametrization, pest, pest management, phenology, phytoplasmas, Pierce's disease, population dynamics, prediction, Scaphoideus titanus, spatial distribution, spider mites, stochastic, validation, vectors, viticulture, Vitis vinifera, and Xylella fastidiosa. Usually, a combination included one keyword related to grapevine (e.g., Vitis, grapevine, etc.), one keyword related to the pest (e.g., spider mites), and one keyword related to modelling (e.g., modelling, prediction, etc.). When the searched pest was a grapevine specialist (e.g., Scaphoideus titanus), the keyword related to grapevine was omitted.

\section{What Is a Model?}

The definition of a mathematical model is a description of a system using mathematical concepts and language to facilitate proper explanation of a system or to study the effects of different components and to make predictions [7]. The term "modelling" refers to the building process of a model itself and includes the following steps: identify what is important, list the quantities that can be observed (outputs), list the variables that can be controlled (inputs), and define the constraints of the system [8].

Mathematical models may be divided into deterministic and stochastic. Deterministic models are defined by the parameters and the initial conditions chosen only; many of them are based on ordinary differential equations (ODEs). On the other hand, stochastic models include a certain rate of randomness; models derived from data fitting are typically stochastic [9]. Models may also be divided into continuous and discrete depending on the type of output variable [9]. In addition, we can discern between analytical and simulation (computer) models [9].

Finally, descriptive or process models are as such when they explicitly incorporate biological aspects of the phenomenon investigated. The opposite is statistical models, derived solely from data fitting: whilst many of them are useful in identifying patterns and other biological phenomena, statistical models are not conceptually based and therefore give no a priori explanation [9]. Nevertheless, statistical models are used often to validate the results of process modelling, fitting them to independent data. Given the wide array of statistical models concerning insect pests in viticulture, they are not covered by this review. 


\section{Predicted Phenomena in Entomology}

\subsection{Pest Population Growth and Dynamic}

Developmental (phenology) models are usually based on temperature, which is the main abiotic factor driving the physiological response of poikilothermic organisms, including insects [6,10]. The first such models were built using degree days (DD) and minimum cardinal temperatures [11,12]. These models were mostly linear; however, the response to temperature by insects has a high nonlinear component. A temperature-dependent nonlinear growth function was theorized by Logan et al. [13] and subsequently improved by Briére [10]. This function models the developmental rate of arthropods under constant temperatures by estimating minimum, optimum, and maximum temperatures of development. Concerning grapevine pests, it has been applied to a leafhopper [14] and to the grape berry moth [15]. This and other models applied to these pests are discussed later.

A further improvement on this issue is given by distributed delay models (DDMs). These models are derived from both phenological and demographical models and are used when the response to a driven factor is not immediate but happens with a given delay [16-18]. This is typical of insect developmental dynamics, as different individuals do not behave as a cohort but they grow and molt at different times, overlapping themselves. DDMs are therefore typically continuous models [6]. Thinking in population rather than single individual terms, we have from age-structured to stage-structured models [18-20]. Stage-structured models are particularly helpful in entomology, as population dynamics of insects involve different life stages with different growth rates, responses to external stimuli, and so on. In pest-management terms, predicting the occurrence of a particular life stage is crucial for timing sprays, release of a natural enemy, and so on. In viticulture, this is particularly interesting concerning Scaphoideus titanus Ball (Hemiptera: Cicadellidae) for targeting third instar nymphs to avoid phytoplasmas' acquisition [21,22].

\subsection{Pest Invasion Risk}

Another issue needing investigation is not "when" but "where" an insect pest occurs. In this case, what matters is not time, but space. The occurrence of an insect pest in space could be investigated at different scale levels: plot-scale (e.g., a single vineyard), landscape scale (a vine-growing area), country-scale, and so on. The importance of landscape ecology in pest management has increased over the last 15 years, as the problem has been more frequently approached at the landscape- rather than plot-scale. Spatial distribution models are relatively recent, but connected research is increasing exponentially since the birth of Geographic information system (GIS)-based tools, which allow us to handle georeferenced data [23].

Many of these models aim to forecast the global distribution of pests under a climate change scenario. Pest-risk assessment is crucial in forecasting the introduction and, more importantly, the establishment of alien species into a new area in order to put in place plant protection procedures. The influence of climate change on viticulture involves the host plant, insect pests, and their natural enemies [24]. The so-called species' distribution models (SDMs) include ecological niches (e.g., bio-climatic models, BIOCLIM), a generic algorithm for rule set prediction, maximum entropy, and CLIMEX (Climate Modelling of Extreme Events) models. Ecological niche models (ENMs) represent an approximation of the species' realized niche (resulting in its occupied geographical space) and not of its fundamental niche (ecological space). However, if the fundamental niche is adequately represented, the projection of the model into geographical space represents the potential species' distribution [25]. An evolution of ENM is given by physiologically based demographical models (PBDMs) [26]. CLIMEX, GARP (genetic algorithm for rule-set prediction) models are machine-learned, stochastic processes using presence data only. They search broadly within the search space and then refine solutions showing high values of optimization criteria [27]. Maximum entropy (MAXENT) models are intended to make predictions from incomplete information. They estimate a target probability distribution by finding the probability distribution of maximum entropy given a set of constraints representing 
the incomplete information about our target distribution. MAXENT are machine-learning models working with presence data only [25,28]. CLIMEX models, on the other hand, are entirely based on climatic factors. The inference is that simple: given the current distribution of a species, the required climatic conditions can be inferred $[29,30]$.

\section{Modelling Grapevine Pests}

A list of the available models investigating different aspects of grapevine pests is presented in Table 1. The most covered aspect is development and population dynamics $(38 \%)$, followed by species distribution and climate change (33\%) (Figure 1). Concerning different taxa, the vectors of Xylella fastidiosa are the most represented (29\%), followed by the European grape berry moth (21\%), and S. titanus (19\%) (Figure 2). These three groups are presented in detail as case studies, whereas the others are covered after.

Table 1. List of published models investigating different biological aspects of grapevine pests.

\begin{tabular}{|c|c|c|c|c|c|c|}
\hline Order & Species & $\begin{array}{l}\text { Development } \\
\text { and Population } \\
\text { Dynamics }\end{array}$ & $\begin{array}{l}\text { Species } \\
\text { Distribution and } \\
\text { Climate Change }\end{array}$ & $\begin{array}{l}\text { Flight and } \\
\text { Feeding } \\
\text { Threshold }\end{array}$ & $\begin{array}{c}\text { Spatial } \\
\text { Distribution, } \\
\text { Ecology }\end{array}$ & Epidemiology \\
\hline \multirow{5}{*}{ Hemiptera } & Halyomorpha halys & [31] & {$[32,33]$} & \multirow{5}{*}{ [41] } & & \\
\hline & $\begin{array}{l}\text { Vectors of Xylella } \\
\text { fastidiosa }\end{array}$ & [34-38] & {$[26,39,40]$} & & [42] & [43-46] \\
\hline & $\begin{array}{c}\text { Other leafhop- } \\
\text { pers/planthoppers }\end{array}$ & {$[47,48]$} & & & & \\
\hline & $\begin{array}{l}\text { Bois noir and its } \\
\text { vectors }\end{array}$ & \multirow[b]{2}{*}[14,22]{} & & & \multirow[b]{2}{*}{ [54] } & [49] \\
\hline & $\begin{array}{l}\text { Scaphoideus titanus } \\
\text { Mealybugs }\end{array}$ & & $\begin{array}{c}{[50-53]} \\
{[56]}\end{array}$ & & & $\begin{array}{c}{[20,53,55]} \\
{[57]}\end{array}$ \\
\hline \multirow{3}{*}{ Lepidoptera } & Lobesia botrana & {$[11,15,58]$} & \multirow{3}{*}{$\begin{array}{c}{[59-62]} \\
{[64]}\end{array}$} & \multirow[t]{3}{*}[12,63]{} & & \\
\hline & Epiphyas postvittana & & & & & \\
\hline & Criptoblabes gnidiella & [65] & & & & \\
\hline Coleoptera & Xylotrechus arvicola & [66] & & & & \\
\hline Diptera & Drosophila suzukii & {$[67,68]$} & [69] & & & \\
\hline Acari & Spider mites & {$[70,71]$} & & & & \\
\hline
\end{tabular}

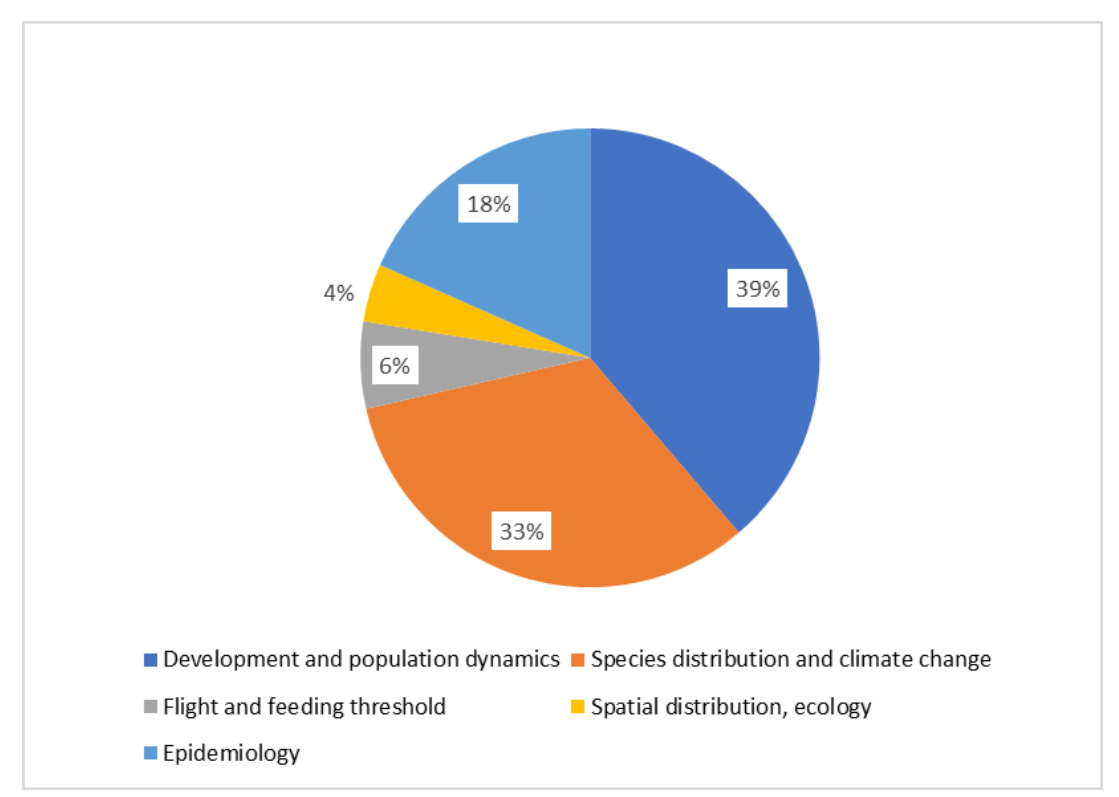

Figure 1. Distribution of published models investigating different life aspects of grapevine pests. 


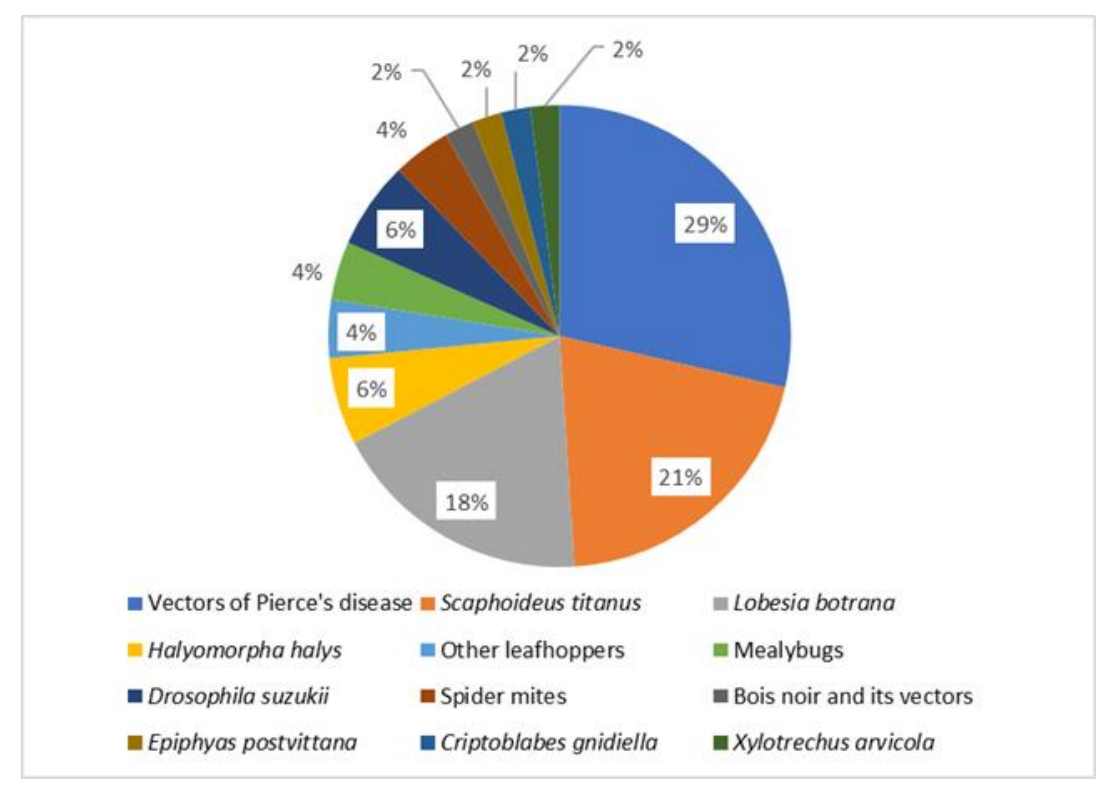

Figure 2. Distribution of published models investigating different taxa of grapevine pests.

\subsection{Case Study 1: Grapevine Yellows and Their Vectors}

Diseases caused by phytoplasmas, commonly referred to as "yellows", transmitted by insect vectors are among the most threatening to grapevine. Since so far there is no cure, particular attention has been paid to vector control. The most important are Flavescence dorée (FD) and Bois noir (BN), which are transmitted by different vector species [21]. From a modelling point of view, we can distinguish between models referring to aspects of vector biology only and models that encompasses both disease and vector. The majority of models are about FD and/or its main vector $S$. titanus.

The first models concerning $S$. titanus aimed to forecast the appearance of nymphs and adults. Rigamonti et al. [22] developed a stochastic model to forecast the appearance of N1, N3, and adults for insecticide timing (especially insect growth regulators). This model is currently used in Switzerland within adaptative management (AM) strategies. Subsequently, another stochastic model for the multiannual infestation pattern of $S$. titanus on grapevine was derived from this one [72]. On the other hand, the duration of all life stages in S. titanus (including eggs) at constant temperatures was studied basing on Briére's equations, and the obtained deterministic model was applied to field conditions using R software [14]. A more comprehensive stochastic, stage-structured model for S. titanus populations was developed taking into account input variables other than temperature, such as plant density and others [20].

Spatial models on $S$. titanus, on the other hand, have been less investigated. These aspects have been studied mainly by means of spatial interpolation techniques such as geostatistical analyses $[73,74]$. However, a study was conducted to forecast the spread of $S$. titanus at the local scale using an Artificial Neural Network (ANN) [54]. ANNs are machine self-learning processes, inspired to brain connections, which estimate one or more variables from a given data set [6].

Other models related to $S$. titanus concern species' distribution and climate change. A survey was made with DIVA-GIS software to forecast the possible spread of $S$. titanus in China [50], and another one was made in Chile using BIOCLIM [52]. Within the frame of a climate change scenario, the adaptation of $S$. titanus to an alpine environment was also investigated [51]. Finally, VITISCLIM ("Vitis and Climate") model was applied in Austria [53].

Epidemiological models were also developed in an attempt to forecast the spread of FD. A stochastic model, based on [20], was developed to model the acquisition, latency, and inoculation process of FD phytoplasmas in grapevine [75]. On the other hand, a deter- 
ministic model was developed to forecast the FD epidemic without referring directly to the vector's population, which is modelled by means of a coupling factor between healthy and infected plants; moreover, this model takes into account the presence of hotbeds, levels of susceptibility of grapevine varieties, and insecticidal sprays [55]. Concerning Bois noir (BN), a model about the long-term response of grapevines to the pathogen was developed using data mining and decision trees [49]. However, this is not an epidemiological but a prognosis model in that it does not model the pattern of disease transmission. It must be said, however, that BN phytoplasma "Ca. Phytoplasma solani" has many insect vectors, depends on many environmental variables, and is therefore very difficult to model from an epidemiological point of view [76].

Finally, an approach attempted to model the spread of FD from economic and social points of view [77]. Additionally, a model to evaluate the profitability of replacing symptomatic plants was developed [78]. Modelling the economic impact of pest and/or plant disease management is always a challenge and has been overlooked so far [6].

\subsection{Case Study 2: Grape Berry Moths}

The European grape berry moth Lobesia botrana (Denis and Schiffermuller) is probably one of the most studied pests of grapevine concerning the development and applications of mathematical models. The first models and their evolutions were based on degree days, aimed at predicting flight $[11,12,15,63,79]$. A deterministic model was also developed to calculate diapause length, including the duration of pre- and post-diapausing larvae and diapausing pupae depending on temperature and photoperiod [80]. A stage-structured population model based on partial differential equations (PDAs), permitting to distinguish growth of individuals within a cohort, was also developed: the environmental factors included air temperature, relative humidity, and grape variety [81]. A holistic, physiologically based, demographic model (PBDM), based on a grapevine model with subunits for the growth of leaves, shoots, clusters, and so on and a L. botrana age-structured model, was also developed. This model includes bottom-up and top-down effects [62]. Based on the model by Gutierrez et al. [62], a PBDM was developed to forecast the geographical distribution of the grape berry moth, both present and under a climate change scenario [59]. Another PBDM was based on a stochastic demographic model for a stage-structured population and aimed to support integrated pest management (IPM) strategies [4]. In addition, a MAXENT model was developed to forecast the potential distribution of L. botrana in China [60].

\subsection{Case Study 3: Pierce's Disease and Its Vectors}

Pierce's disease (PD) of grapevine is caused by a bacterium, Xylella fastidiosa subsp. fastidiosa. There are many strains (subspecies) of X. fastidiosa causing different syndromes to many host plants [82]. It is worth remembering that X. fastidiosa subsp. pauca, recently identified in Apulia, Southern Italy, caused the severe decline syndrome named CoDiRo to olive trees [83]. X. fastidiosa is transmitted by xylem-feeding insect vectors such as spittlebugs and sharpshooters $[84,85]$. Some of them have been investigated from a modelling point of view, with or without particular reference to PD, and are reported here.

A first set of papers modelled the physiology and demography of vectors. The most studied vector was the glassy-winged sharpshooter (GWSS) Homalodisca vitripennis (Germar) (H. coagulata (Say)), concerning embryonic development [86], development at constant temperatures, and subsequently its adaptation to Californian climate [37], and population dynamics [34]. Additionally, a temperature-dependent stochastic phenology model was developed [38]. In terms of epidemiology, the patterns of transmission of PD by $H$. vitripennis were modelled with a discrete-time simulation model [44]. Another research, albeit not involving vectors, modelled the response to cold by grapevine infected by $X$. fastidiosa [46], whereas the research proposed by Kyrkou et al. [43] modelled the PD epidemiology depending on infected vines and GWSSs (in the authors' words, the dynamics of vine population under a high PD pressure). A temperature-dependent feeding model of the GWSS was developed to forecast probing [41]. A. latere modelling concerned 
also the development of an egg parasitoid of the GWSS [87]. In terms of species' distribution, both PD [39] and GWSS [26] were investigated. The potential spread of three different subspecies of X. fastidiosa, namely fastidiosa, pauca, and multiplex, were studied with a species distribution model [39].

Other acknowledged vectors of PD are less investigated, probably because GWSS is the only species overwintering in the adult stage and capable therefore of propagating the disease from year to year [84]. In Europe, the common spittlebugs Philaenus spumarius L. and Neophilaenus campestris L. have been associated to CodiRo, and P. spumarius has been acknowledged as a vector [85]. However, to date, there is no or little literature about modelling life aspects of spittlebugs besides a study about the influence of temperature on Neophilaenus sp. [35].

\subsection{Other Species}

One of the main emerging pests is the brown marmorated stink bug (BMSB), Halyomorpha halys (Stål) (Hemiptera: Pentatomidae). A temperature-dependent model was implemented to forecast oviposition [31], whereas other models are about its potential distribution [32,33]. Within coleopterans, the potential spread of Xylotrechus arvicola (Oliver) (Coleoptera: Cerambycidae) in Spain following climate change scenarios was studied by means of a degree-days-based model [66]. Concerning mealybugs, which are important pests and vectors of viruses [24], a forecast model about the spread of Planococcus ficus Signoret in California, including pest phenological and demographical aspects, as well as the physiology of grapevine and the influence of climate on natural enemies was developed [56], whereas a spatial model was proposed to forecast spatial distribution of leaf roll affected grapevines [57]. The spotted-winged Drosophila suzukii Matsumura (Diptera: Drosophilidae) is another pest of some concern on grapevine [88]. However, to date, there are no models developed with respect to its relationships with grapevine. A generalized additive model (GAM) was used to predict flight based upon some environmental and weather factors, namely some $\mathrm{T}$ and $\mathrm{RH}$ parameters: this model was developed with respect to blueberry [67], whereas a SDM modelled its expansion range [69]. Recently, a physiological model, based on the equations of Logan and Briére, was also published: this model forecasted the development, fertility, and mortality of D. suzukii [68].

Spider mites (Arachnida: Acari) are another important category of pests of grapevine. However, they are scarcely explored from a modelling point of view, as a data-fitting approach is usually preferred. The most investigated matter is prey vs. predator interaction. Such an approach was applied to Tetranychus urticae Koch and a predatory mite using the Penna model [89]. Another stage-specific predation model was developed with respect to T. urticae and Phytoseiulus persimilis Athias-Henriot [90]. A temperature-dependent model according to Logan [13] was developed with respect to the yellow mite Eotetranychus hirsti Pritchard and Baker [71], and a degree-days-based model was used to predict the oviposition by T. urticae [70]. Finally, an empirical transition matrix model between Panonychus ulmi Koch and two predatory mites belonging to the families Phytoseiidae and Stigmeidae was proposed [91].

\section{Decision Support Systems: Present and Future}

Decision support systems (DSS) should be the final purpose of a model designed for pest management in viticulture; that is where such a model should end, being available to vine growers, wine makers, technical support professionals, plant-protection services, and other stakeholders. Underutilization in practical agriculture is one of the main issues in mathematical models [2]. Another problem is the compartmental approach that drives many applications of models [6]. Some models are currently used, e.g., the "Modello Lobesia" in Piedmont, Italy, to forecast the European berry moth [92]. However, a holistic approach, including meteorology, insect phenology, demography and spatial distribution, plant phenology, and the economic impact of choices made by vine growers, is desired. For instance, in order to make existing models available to stakeholders, a portal (a website) 
encompassing different compartments adapted to different vine growing areas, organic vs. conventional pest management, plant phenology vs. bud break, and blossoming/flowering depending also on vine variety, may be developed. Moreover, a distinction between shortand long-term decision-support systems should be taken into account. Short-term decisions are made within season (e.g., timing of insecticidal sprays), whereas long-term decisions have to do with the choice of area when making new plantations. This latter issue is particularly critical when dealing with plant diseases transmitted by vectors: the prediction of a long-term effect of surrounding hotbeds on a new vineyard may drive the choice of a given geographical area [55]. Of course, models should be included into the frame of integrated pest management along with other methods or techniques such as sampling plans $[93,94]$.

The website may be structured in a way to allow scientists to directly upload recently published research, and a search function within the website would then allow users to retrieve information promptly and to make decisions, for instance, about choosing the optimal timing to target two or more pests having partially overlapping life cycles with one single spray of insecticide given the temperature-dependent population dynamics simulated by the models or putting together spread potential models, thermal threshold models, and population growth models to forecast the acclimation and expansion of an alien species over a non-infested areas in order to make decisions about the extension of buffer zones by plant-protection services.

The greatest challenges are probably the climate change scenarios (particularly global warming) and the potential introduction of alien species into different viticultural areas. However, these two issues differ in terms of increase over time. Global warming occurs gradually but is almost certain and is therefore easy to simulate and forecast over the long period: from an entomological point of view, some grapevine pests may spread farther northwards or above sea level $[51,59]$ along with grapevine itself $[95,96]$. On the other hand, the introduction of alien species is often an abrupt event, requiring quick adaptations: from this point of view, it is very important to model the potential adaptation of alien species to new viticultural areas well before they are detected $[50,52]$ in order to consider in advance the required countermeasures.

In conclusion, the literature on prediction models about pests of grapevine is wide and adequately covers the most important biological and epidemiological aspects, but an effort to put together this knowledge and to make it useful to vine growers and their stakeholders is needed.

Author Contributions: Conceptualization, F.L. and A.A.; literature search, F.L.; writing-original draft preparation, F.L.; writing-review and editing: A.A.; supervision, A.A. All authors have read and agreed to the published version of the manuscript.

Funding: This research received no external funding.

Institutional Review Board Statement: Not applicable.

Conflicts of Interest: The authors declare no conflict of interest.

\section{References}

1. Pertot, I.; Caffi, T.; Rossi, V.; Mugnai, L.; Hoffmann, C.; Grando, M.S.; Gary, C.; Lafond, D.; Duso, C.; Thiery, D.; et al. A critical review of plant protection tools for reducing pesticide use on grapevine and new perspectives for the implementation of IPM in viticulture. Crop Prot. 2017, 97, 70-84. [CrossRef]

2. Rossi, V.; Salinari, F.; Poni, S.; Caffi, T.; Bettati, T. Addressing the implementation problem in agricultural decision support systems: The example of vite.net (R). Comput. Electron. Agric. 2014, 100, 88-99. [CrossRef]

3. Rossi, V.; Caffi, T.; Salinari, F. Helping farmers face the increasing complexity of decision-making for crop protection. Phytopathol. Mediterr. 2012, 51, 457-479.

4. Gilioli, G.; Pasquali, S.; Marchesini, E. A modelling framework for pest population dynamics and management: An application to the grape berry moth. Ecol. Model. 2016, 320, 348-357. [CrossRef] 
5. Venette, R.C.; Kriticos, D.J.; Magarey, R.D.; Koch, F.H.; Baker, R.H.A.; Worner, S.P.; Raboteaux, N.N.G.; McKenney, D.W.; Dobesberger, E.J.; Yemshanov, D.; et al. Pest risk maps for invasive alien species: A roadmap for improvement. Bioscience 2010, 60, 349-362. [CrossRef]

6. Tonnang, H.E.Z.; Herve, B.D.B.; Biber-Freudenberger, L.; Salifu, D.; Subramanian, S.; Ngowi, V.B.; Guimapi, R.Y.A.; Anani, B.; Kakmeni, F.M.M.; Affognong, H.; et al. Advances in crop insect modelling methods-Towards a whole system approach. Ecol. Model. 2017, 354, 88-103. [CrossRef]

7. Abramowitz, M.; Stegun, I.A.; Romer, R.H. Handbook of mathematical functions with formulas, graphs, and mathematical tables. Am. J. Phys. 1988, 56, 958. [CrossRef]

8. Ningthoujam, S.; Talukdar, A.D.; Sarker, S.D.; Nahar, L.; Choudhury, M. Prediction of medicinal properties using mathematical models and computation, and selection of plant materials. Comput. Phytochem. 2018, 43-73. [CrossRef]

9. Peck, S.L. A tutorial for understanding ecological modeling papers for the nonmodeler. Am. Entomol. 2000, 46, 40-49. [CrossRef]

10. Briére, J.F.; Pracros, P.; Le Roux, A.Y.; Pierre, J.S. A novel rate model of temperature-dependent development for arthropods. Environ. Entomol. 1999, 28, 22-29. [CrossRef]

11. Milonas, P.G.; Savopoulou-Soultani, M.; Stavridis, D.G. Day-degree models for predicting the generation time and flight activity of local populations of Lobesia botrana (Den. \& Schiff.) (Lep., Tortricidae) in Greece. J. Appl. Entomol. 2001, 125, 515-518. [CrossRef]

12. Gallardo, A.; Ocete, R.; Lopez, M.A.; Maistrello, L.; Ortega, F.; Semedo, A.; Soria, F.J. Forecasting the flight activity of Lobesia botrana (Denis \& Schiffermuller) (Lepidoptera, Tortricidae) in Southwestern Spain. J. Appl. Entomol. 2009, 133, 626-632. [CrossRef]

13. Logan, J.A.; Wollkind, D.J.; Hoyt, S.C.; Tanigoshi, L.K. An analytic model for description of temperature dependent rate phenomena in arthropods. Environ. Entomol. 1976, 5, 1133-1140. [CrossRef]

14. Falzoi, S.; Lessio, F.; Spanna, F.; Alma, A. Influence of temperature on the embryonic and post-embryonic development of Scaphoideus titanus (Hemiptera: Cicadellidae), vector of grapevine Flavescence doree. Int. J. Pest Manag. 2014, 60, 246-257. [CrossRef]

15. Briére, J.F.; Pracros, P. Comparison of temperature-dependent growth models with the development of Lobesia botrana (Lepidoptera: Tortricidae). Environ. Entomol. 1998, 27, 94-101. [CrossRef]

16. Manetsch, T.J. Time-varying distributed delays and their use in aggregative models of large systems. IEEE Trans. Syst. Man Cybern. 1976, 8, 547-553. [CrossRef]

17. Gilbert, E.; Powell, J.A.; Logan, J.A.; Bentz, B.J. Comparison of three models predicting developmental milestones given environmental and individual variation. Bull. Math. Biol. 2004, 66, 1821-1850. [CrossRef] [PubMed]

18. Liu, S.Q.; Chen, L.S.; Agarwal, R. Recent progress on stage-structured population dynamics. Math. Comput. Model. 2002, 36, 1319-1360. [CrossRef]

19. Wang, Y.; Liu, X.N.; Wei, Y.J. Dynamics of a stage-structured single population model with state-dependent delay. Adv. Differ. Equ. 2018, 2018, 364. [CrossRef]

20. Maggi, F.; Marzachi, C.; Bosco, D. A stage-structured model of Scaphoideus titanus in vineyards. Environ. Entomol. 2013, 42, 181-193. [CrossRef] [PubMed]

21. Alma, A.; Lessio, F.; Nickel, H. Insects as phytoplasma vectors: Ecological and epidemiological aspects. In Phytoplasmas: Plant Pathogenic Bacteria-II. Transmission and Management of Phytoplasma-Associated Diseases; Bertaccini, A., Weintraub, P.G., Rao, G.P., Mori, N., Eds.; Springer: Singapore, 2019; pp. 1-25.

22. Rigamonti, I.E.; Jermini, M.; Fuog, D.; Baumgaertner, J. Towards an improved understanding of the dynamics of vineyardinfesting Scaphoideus titanus leafhopper populations for better timing of management activities. Pest Manag. Sci. 2011, 67, 1222-1229. [CrossRef]

23. Liebhold, A.M.; Rossi, R.E.; Kemp, W.P. Geostatistics and geographic information systems in applied insect ecology. Annu. Rev. Entomol. 1993, 38, 303-327. [CrossRef]

24. Reineke, A.; Thiery, D. Grapevine insect pests and their natural enemies in the age of global warming. J. Pest Sci. 2016, 89, 313-328. [CrossRef]

25. Phillips, S.J.; Anderson, R.P.; Schapire, R.E. Maximum entropy modeling of species geographic distributions. Ecol. Model. 2006, 190, 231-259. [CrossRef]

26. Gutierrez, A.P.; Ponti, L.; Hoddle, M.; Almeida, R.P.P.; Irvin, N.A. Geographic distribution and relative abundance of the invasive glassy-winged sharpshooter: Effects of temperature and egg parasitoids. Environ. Entomol. 2011, 40, 755-769. [CrossRef]

27. Anderson, R.P.; Lew, D.; Peterson, A.T. Evaluating predictive models of species' distributions: Criteria for selecting optimal models. Ecol. Model. 2003, 162, 211-232. [CrossRef]

28. Warren, D.L.; Seifert, S.N. Ecological niche modeling in Maxent: The importance of model complexity and the performance of model selection criteria. Ecol. Appl. 2011, 21, 335-342. [CrossRef] [PubMed]

29. Sutherst, R.W.; Maywald, G.F.; Kriticos, D. CLIMEX Version 3. User's Guide; Hearne Scientific Software Pty Ltd.: Melbourne, Australia, 2007; p. 131.

30. Sutherst, R.W.; Maywald, G.F. CLIMEX-A biogeographical approach to entomology. In Pest Management: Future Challenges, Proceedings of the 6th Australasian Applied Entomological Research Conference, Brisbane, Australia, 29 September-2 October 1998; Zalucki, M.P., Drew, R., White, G.G., Eds.; University of Qld Press: Brisbane, Australia, 1998; Volumes 1-2, pp. 344-345.

31. Baek, S.; Hwang, A.; Kim, H.; Lee, H.; Lee, J.H. Temperature-dependent development and oviposition models of Halyomorpha halys (Hemiptera: Pentatomidae). J. Asia Pac. Entomol. 2017, 20, 367-375. [CrossRef] 
32. Fraser, D.; Kumar, S.; Aguilar, G. Mapping the potential global range of the brown marmorated stink bug, Halyomorpha halys, with particular reference to New Zealand. Climate 2017, 5, 75. [CrossRef]

33. Zhu, G.P.; Bu, W.J.; Gao, Y.B.; Liu, G.Q. Potential geographic distribution of brown marmorated stink bug invasion (Halyomorpha halys). PLoS ONE 2012, 7, e31246. [CrossRef]

34. Yoon, J.M.; Hrynkiv, V.; Morano, L.; Nguyen, A.T.; Wilder, S.; Mitchell, F. Mathematical modeling of glassy-winged sharpshooter population. Math. Biosci. Eng. 2014, 11, 667-677. [CrossRef]

35. Bostanian, N.J.; Bourgeois, G.; Vincent, C.; Plouffe, D.; Trudeau, M.; Lasnier, J. Modeling leafhopper nymphs in temperate vineyards for optimal sampling. Environ. Entomol. 2006, 35, 1477-1482. [CrossRef]

36. Banks, H.T.; Banks, J.E.; Cody, N.G.; Hoddle, M.S.; Meade, A.E. Population model for the decline of Homalodisca vitripennis (Hemiptera: Cicadellidae) over a ten-year period. J. Biol. Dyn. 2019, 13, 422-446. [CrossRef] [PubMed]

37. Pilkington, L.J.; Lewis, M.; Jeske, D.; Hoddle, M.S. Calculation and thematic mapping of demographic parameters for Homalodisca vitripennis (Hemiptera: Cicadellidae) in California. Ann. Entomol. Soc. Am. 2014, 107, 424-434. [CrossRef]

38. Castle, S.J.; Naranjo, S.E.; Bi, J.L.; Byrne, F.J.; Toscano, N.C. Phenology and demography of Homalodisca coagulata (Hemiptera: Cicadellidae) in Southern California citrus and implications for management. Bull. Entomol. Res. 2005, 95, 621-634. [CrossRef] [PubMed]

39. Godefroid, M.; Cruaud, A.; Streito, J.C.; Rasplus, J.Y.; Rossi, J.P. Xylella fastidiosa: Climate suitability of European continent. Sci. Rep. 2019, 9. [CrossRef] [PubMed]

40. Lopez, R.; Mizell, R.F.; Andersen, P.C.; Brodbeck, B.V. Overwintering biology, food supplementation and parasitism of eggs of Homalodisca coagulata (Say) (Homoptera: Cicadellidae) by Gonatocerus ashmeadi Girault and Gonatocerus morrilli (Howard) (Hymenoptera: Mymaridae). J. Entomol. Sci. 2004, 39, 214-222. [CrossRef]

41. Son, Y.; Groves, R.L.; Daane, K.M.; Morgan, D.J.W.; Krugner, R.; Johnson, M.W. Estimation of feeding threshold for Homalodisca vitripennis (Hemiptera: Cicadellidae) and its application to prediction of overwintering mortality. Environ. Entomol. 2010, 39, 1264-1275. [CrossRef]

42. Mizell, R.F.; Tipping, C.; Andersen, P.C.; Brodbeck, B.V.; Hunter, W.B.; Northfield, T. Behavioral model for Homalodisca vitripennis (Hemiptera: Cicadellidae): Optimization of host plant utilization and management implications. Environ. Entomol. 2008, 37, 1049-1062. [CrossRef]

43. Kyrkou, I.; Pusa, T.; Ellegaard-Jensen, L.; Sagot, M.F.; Hansen, L.H. Pierce's disease of grapevines: A review of control strategies and an outline of an epidemiological model. Front. Microbiol. 2018, 9. [CrossRef]

44. Daugherty, M.P.; Almeida, R.P.P. Understanding how an invasive vector drives pierce's disease epidemics: Seasonality and vine-to-vine spread. Phytopathology 2019, 109, 277-285. [CrossRef] [PubMed]

45. Dickman, A.G.; Dickman, R. Computational model of a vector-mediated epidemic. Am. J. Phys. 2015, 83, 468-474. [CrossRef] [PubMed]

46. Lieth, J.H.; Meyer, M.M.; Yeo, K.H.; Kirkpatrick, B.C. Modeling cold curing of pierce's disease in Vitis vinifera 'Pinot Noir' and 'Cabernet Sauvignon' grapevines in California. Phytopathology 2011, 101, 1492-1500. [CrossRef]

47. Cerutti, F.; Baumgartner, J.; Delucchi, V. The dynamics of grape leafhopper Empoasca vitis Gothe populations in Switzerland and the implications for habitat management. Biocontrol Sci. Technol. 1991, 1, 177-194. [CrossRef]

48. Kim, M.J.; Baek, S.; Lee, J.H. Egg hatching and first instar falling models of Metcalfa pruinosa (Hemiptera: Flatidae). Insects 2020, 11, 345. [CrossRef]

49. Rotter, A.; Nikolic, P.; Turnsek, N.; Kogovsek, P.; Blejec, A.; Gruden, K.; Dermastia, M. Statistical modeling of long-term grapevine response to 'Candidatus Phytoplasma solani' infection in the field. Eur. J. Plant Pathol. 2018, 150, 653-668. [CrossRef]

50. Ge, Q.; Wen, F. Predicting the potential geographical distribution of flavescence doree and its vector Scaphoideus titanus Ball in China using DIVA-GIS. Acta Phytophylacica Sin. 2006, 33, 51-58.

51. Rigamonti, I.E.; Mariani, L.; Cola, G.; Jermini, M.; Baumgartner, J. Abrupt and gradual temperature changes influence on the climatic suitability of Northwestern Alpine grapevine-growing regions for the invasive grape leafhopper Scaphoideus titanus Ball (Hemiptera, Cicadellidae). Acta Oecologica Int. J. Ecol. 2018, 91, 22-29. [CrossRef]

52. Quiroga, N.; Ivulic, D.; Saaverda, M.; Sandoval-Rodriguez, A.; Infante, R.; Morales, L.; Fiore, N. Risk analysis of the establishment of Scaphoideus titanus, vector of "flavescence dorée" phytoplasma in grapevine, under current and estimated climate change in Chle. Phytopathogenic Mollicutes 2017, 7, 39-44. [CrossRef]

53. Steffek, R.; Reisenzein, H.; Strauss, G.; Leichtfried, T.; Hofrichter, J.; Kopacka, I.; Schwarz, M.; Pusterhofer, J.; Biedermann, R.; Renner, W.; et al. VitisCLIM, a project modelling epidemiology and economic impact of grapevine 'flavescence doree' phytoplasma in Austrian viticulture under a climate change scenario. Bull. Insectol. 2011, 64, S191-S192.

54. Lessio, F.; Mondino, E.B.; Alma, A. Spatial patterns of Scaphoideus titanus (Hemiptera: Cicadellidae): A geostatistical and neural network approach. Int. J. Pest Manag. 2011, 57, 205-216. [CrossRef]

55. Lessio, F.; Portaluri, A.; Paparella, F.; Alma, A. A mathematical model of flavescence doree epidemiology. Ecol. Model. 2015, 312, 41-53. [CrossRef]

56. Gutierrez, A.P.; Daane, K.M.; Ponti, L.; Walton, V.M.; Ellis, C.K. Prospective evaluation of the biological control of vine mealybug: Refuge effects and climate. J. Appl. Ecol. 2008, 45, 524-536. [CrossRef]

57. Atallah, S.S.; Gomez, M.I.; Conrad, J.M.; Nyrop, J.P. A plant-level, spatial, bioeconomic model of plant disease diffusion and control: Grapevine leafroll disease. Am. J. Agric. Econ. 2015, 97, 199-218. [CrossRef] 
58. Castex, V.; de Cortazar-Atauri, I.G.; Calanca, P.; Beniston, M.; Moreau, J. Assembling and testing a generic phenological model to predict Lobesia botrana voltinism for impact studies. Ecol. Model. 2020, 420. [CrossRef]

59. Gutierrez, A.P.; Ponti, L.; Gilioli, G.; Baumgartner, J. Climate warming effects on grape and grapevine moth (Lobesia botrana) in the Palearctic region. Agric. For. Entomol. 2018, 20, 255-271. [CrossRef]

60. Lv, W.; Li, Z.; Wu, X.; Ni, W.; Qv, W. Maximum Entropy Niche-Based Modeling (Maxent) of potential geographical distributions of Lobesia botrana (Lepidoptera: Tortricidae) in China. In Computer and Computing Technologies in Agriculture, Proceedings of the 5th International Conference in Computer and Computing Technologies in Agriculture, Beijing, China, 29-31 October 2011; Li, D., Chen, Y., Eds.; Springer: Berlin/Heidelberg, Germany, 2012. Part III. pp. 239-246.

61. Perez-De la O, B.; Lopez-Martinez, V.; Jimenez-Garcia, D.; Campos-Figueroa, M. Model simulation of potential distribution of lobesia botrana (Denis \& Schiffermuller) in grape, Vitis vinifera (L.) vineyard regions of Mexico. Southwest. Entomol. 2016, 41, 693-703.

62. Gutierrez, A.P.; Ponti, L.; Cooper, M.L.; Gilioli, G.; Baumgartner, J.; Duso, C. Prospective analysis of the invasive potential of the European grapevine moth Lobesia botrana (Den. \& Schiff.) in California. Agric. For. Entomol. 2012, 14, 225-238. [CrossRef]

63. Amo-Salas, M.; Ortega-Lopez, V.; Harman, R.; Alonso-Gonzalez, A. A new model for predicting the flight activity of Lobesia botrana (Lepidoptera: Tortricidae). Crop Prot. 2011, 30, 1586-1593. [CrossRef]

64. He, S.Q.; Worner, S.P.; Ikeda, T. Modeling the potential global distribution of light brown apple moth Epiphyas postvittana (Lepidoptera: Tortricidae) using CLIMEX. J. Asia Pac. Entomol. 2012, 15, 479-485. [CrossRef]

65. Vidart, M.V.; Mujica, M.V.; Calvo, M.V.; Duarte, F.; Bentancourt, C.M.; Franco, J.; Scatoni, I.B. Relationship between male moths of Cryptoblabes gnidiella (Milliere) (Lepidoptera: Pyralidae) caught in sex pheromone traps and cumulative degree-days in vineyards in southern Uruguay. SpringerPlus 2013, 2. [CrossRef]

66. Soria, F.J.; Lopez, M.A.; Perez, M.A.; Maistrello, L.; Armendariz, I.; Ocete, R. Predictive model for the emergence of Xylotrechus arvicola (Coleoptera: Cerambycidae) in La Rioja vineyards (Spain). Vitis 2013, 52, 91-96.

67. Leach, H.; van Timmeren, S.; Wetzel, W.; Isaacs, R. Predicting within- and between-year variation in activity of the invasive spotted wing Drosophila (Diptera: Drosophilidae) in a temperate region. Environ. Entomol. 2019, 48, 1223-1233. [CrossRef]

68. Rossini, L.; Contarini, M.; Giarruzzo, F.; Assennato, M.; Speranza, S. Modelling Drosophila suzukii adult male populations: A physiologically based approach with validation. Insects 2020, 11, 751. [CrossRef]

69. de la Vega, G.J.; Corley, J.C. Drosophila suzukii (Diptera: Drosophilidae) distribution modelling improves our understanding of pest range limits. Int. J. Pest Manag. 2019, 65, 217-227. [CrossRef]

70. Raworth, D.A. Initiation of oviposition after winter diapause in the spider mite Tetranychus urticae (Acari: Tetranychidae): Prediction and historical patterns. Popul. Ecol. 2007, 49, 201-210. [CrossRef]

71. Dolatyar, S.; Jafari, S.; Pakyari, H. Effect of temperature on the development of Eotetranychus hirsti (Tetranychidae) on fig leaves. Acarologia 2015, 55, 247-254. [CrossRef]

72. Rigamonti, I.E.; Trivellone, V.; Jermini, M.; Fuog, D.; Baumgaertner, J. Multiannual infestation patterns of grapevine plant inhabiting Scaphoideus titanus (Hemiptera: Cicadellidae) leafhoppers. Can. Entomol. 2014, 146, 67-79. [CrossRef]

73. Lessio, F.; Tota, F.; Alma, A. Tracking the dispersion of Scaphoideus titanus Ball (Hemiptera: Cicadellidae) from wild to cultivated grapevine: Use of a novel mark-capture technique. Bull. Entomol. Res. 2014, 104, 432-443. [CrossRef] [PubMed]

74. Riolo, P.; Minuz, R.L.; Landi, L.; Nardi, S.; Ricci, E.; Righi, M.; Isidoro, N. Population dynamics and dispersal of Scaphoideus titanus from recently recorded infested areas in central-eastern Italy. Bull. Insectol. 2014, 67, 99-107.

75. Maggi, F.; Bosco, D.; Marzachì, C. Dynamics of acquisition and transmission of "flavescence dorée" phytoplasma in grapevine. Phytopathogenic Mollicutes 2014, 4, 59-71. [CrossRef]

76. Jovic, J.; Riedle-Bauer, M.; Chuche, J. Vector role of cixiids and other planthopper species. In Transmission and Management of Phytoplasma-Associated Diseases; Bertaccini, A., Weintraub, P.G., Rao, G.P., Mori, N., Eds.; Springer: Singapore, 2019; Volume 2, pp. 79-114.

77. Ay, J.S.; Gozlan, E. Disease dispersion as a spatial interaction: The case of Flavescence Doree. Nat. Resour. Model. 2020, 33. [CrossRef]

78. Pavan, F.; Mori, N.; Bressan, S.; Mutton, P. Control strategies for grapevine phytoplasma diseases: Factors influencing the profitability of replacing symptomatic plants. Phytopathol. Mediterr. 2012, 51, 11-22.

79. Rossini, L.; Severini, M.; Contarini, M.; Speranza, S. EntoSim, a ROOT-based simulator to forecast insects' life cycle: Description and application in the case of Lobesia botrana. Crop Prot. 2020, 129. [CrossRef]

80. Baumgartner, J.; Gutierrez, A.P.; Pesolillo, S.; Severini, M. A model for overwintering process of European grapevine moth Lobesia botrana (Denis \& Schiffermuller) (Lepidoptera, Tortricidae) populations. J. Entomol. Acarol. Res. 2012, 44, 8-16.

81. Ainseba, B.; Picart, D.; Thiery, D. An innovative multistage, physiologically structured, population model to understand the European grapevine moth dynamics. J. Math. Anal. Appl. 2011, 382, 34-46. [CrossRef]

82. Almeida, R.P.P.; Nascimento, F.E.; Chau, J.; Prado, S.S.; Tsai, C.W.; Lopes, S.A.; Lopes, J.R.S. Genetic structure and biology of Xylella fastidiosa strains causing disease in citrus and coffee in Brazil. Appl. Environ. Microbiol. 2008, 74, 3690-3701. [CrossRef] [PubMed]

83. Saponari, M.; Boscia, D.; Nigro, F.; Martelli, G.P. Identification of DNA sequences related to Xylella fastidiosa in oleander, almond and olive trees exhibiting leaf scorch symptoms in Apulia (Southern Italy). J. Plant Pathol. 2013, 95, 668. 
84. Redak, R.A.; Purcell, A.H.; Lopes, J.R.S.; Blua, M.J.; Mizell, R.F.; Andersen, P.C. The biology of xylem fluid-feeding insect vectors of Xylella fastidiosa and their relation to disease epidemiology. Annu. Rev. Entomol. 2004, 49, 243-270. [CrossRef]

85. Saponari, M.; Loconsole, G.; Cornara, D.; Yokomi, R.K.; de Stradis, A.; Boscia, D.; Bosco, D.; Martelli, G.P.; Krugner, R.; Porcelli, F. Infectivity and transmission of Xylella fastidiosa by Philaenus spumarius (Hemiptera: Aphrophoridae) in Apulia, Italy. J. Econ. Entomol. 2014, 107, 1316-1319. [CrossRef]

86. Al-Wahaibi, A.K.; Morse, J.G. Homalodisca coagulata (Hemiptera: Cicadellidae) embryonic development at constant temperatures. Fla. Entomol. 2003, 86, 477-478. [CrossRef]

87. Son, Y.; Nadel, H.; Baek, S.; Johnson, M.W.; Morgan, D.J.W. Estimation of developmental parameters for adult emergence of Gonatocerus morgani, a novel egg parasitoid of the glassy-winged sharpshooter, and development of a degree-day model. Biol. Control 2012, 60, 233-240. [CrossRef]

88. Mazzetto, F.; Lessio, F.; Giacosa, S.; Rolle, L.; Alma, A. Relationships between Drosophila suzukii and grapevine in North-western Italy: Seasonal presence and cultivar susceptibility. Bull. Insectol. 2020, 73, 29-38.

89. de Oliveira, A.C.S.; Martins, S.G.F.; Zacarias, M.S. An individual-based model for the interaction of the mite Tetranychus urticae (Koch, 1836) with its predator Neoseiulus californicus (McGregor, 1954) (Acari: Tetranychidae, Phytoseiidae). Ecol. Model. 2013, 255, 11-20. [CrossRef]

90. Nachman, G. The effects of prey patchiness, predator aggregation, and mutual interference on the functional response of Phytoseiulus persimilis feeding on Tetranychus urticae (Acari: Phytoseiidae, Tetranychidae). Exp. Appl. Acarol. 2006, 38, 87-111. [CrossRef]

91. Clements, D.R.; Harmsen, R.; Clements, P.J. A mechanistic simulation to complement an empirical transition matrix model of acarine population-dynamics. Ecol. Model. 1991, 59, 257-277. [CrossRef]

92. Baumgärtner, J.; Baronio, P. Phenological model of the flight of Lobesia botrana Den. E Schiif. (Lep. Tortricidae) in relation to the environmental conditions of Emilia-Romagna. Boll. Ist. Ent "G. Grandi" Univ. Bologna. 1989, 43, 157-170.

93. Lessio, F.; Alma, A. Spatial distribution of nymphs of Scaphoideus titanus (Homoptera: Cicadellidae) in grapes, and evaluation of sequential sampling plans. J. Econ. Entomol. 2006, 99, 578-582. [CrossRef] [PubMed]

94. Ifoulis, A.A.; Savopoulou-Soultani, M. Probability distribution, sampling unit, data transformations and sequential sampling of European vine moth, Lobesia botrana (Lepidoptera: Tortricidae) larval counts from Northern Greece vineyards. Eur. J. Entomol. 2007, 104, 753-761. [CrossRef]

95. Duchene, E.; Huard, F.; Dumas, V.; Schneider, C.; Merdinoglu, D. The challenge of adapting grapevine varieties to climate change. Clim. Res. 2010, 41, 193-204. [CrossRef]

96. Mosedale, J.R.; Abernethy, K.E.; Smart, R.E.; Wilson, R.J.; Maclean, I.M.D. Climate change impacts and adaptive strategies: Lessons from the grapevine. Glob. Chang. Biol. 2016, 22, 3814-3828. [CrossRef] [PubMed] 